\title{
Effects of nitrogen deposition on soil and vegetation in primary succession stages in inland drift sands
}

\author{
L. B. Sparrius • J. Sevink • A. M. Kooijman
}

Received: 30 March 2011 /Accepted: 10 October 2011 /Published online: 29 October 2011

(C) The Author(s) 2011. This article is published with open access at Springerlink.com

\begin{abstract}
Background and aims Primary succession was studied in acid inland drift sands. Main research questions were: 1) How do vegetation and soil change during succession? 2) How are soil parameters and species abundance affected by atmospheric nitrogen deposition?

Methods One hundred sixty-five plots were selected in 21 drift sands throughout The Netherlands, divided over eight succession stages from bare sand to dry heath and within a gradient in nitrogen deposition. Vegetation development and soil parameters were described and water-extractable elements measured and differences between high ( $>30 \mathrm{~kg} \mathrm{~N} \mathrm{ha}^{-1}$ year $^{-1}$ ) and lower nitrogen deposition sites calculated.

Results Vegetation cover and height increased during succession. Lichens contributed most to plant species diversity. Thickness of $\mathrm{A}_{h}$ horizon increased and $\mathrm{pH}$ decreased and concentrations of $\mathrm{Fe}, \mathrm{Al}, \mathrm{S}$ increased. Base cations increased as well, despite the drop in $\mathrm{pH}$. Also, water-extractable ammonium, nitrate and phosphate increased, along with the $\mathrm{NH}_{4}: \mathrm{NO}_{3}$ ratio. Sites with high nitrogen deposition had higher $\mathrm{NH}_{4}: \mathrm{NO}_{3}$ and $\mathrm{Al}: \mathrm{Ca}$ ratios, lower $\mathrm{pH}$, higher cover of algae, lower lichen and total species diversity, more Pinus
\end{abstract}

Responsible Editor: Per Ambus.

L. B. Sparrius $(\bowtie) \cdot J$. Sevink $\cdot$ A. M. Kooijman Institute for Biodiversity and Ecosystem Dynamics, University of Amsterdam,

P.O. Box 94248, 1090 GE Amsterdam, The Netherlands

e-mail: 1.b.sparrius@uva.nl sylvestris seedlings and more species of late succession stages.

Conclusions Drift sand succession seems to be mainly driven by an increase in organic matter, but is accelerated by nitrogen deposition.

Keywords Inland dunes $\cdot$ Soil acidification $\cdot$ Base cations $\cdot$ Al:Ca ratio $\cdot$ Lichens

\section{Introduction}

Many studies on soils and vegetation of Western European inland dune habitats focused on floristic and syntaxonomical aspects of the mainly cryptogamdominated vegetation (Daniëls et al. 1993; Masselink 1994; Paus 1997). The study by Hasse (2005) has a broader scope, also paying attention to the soil, and provided a generic classification based on species and soil data, such as $\mathrm{pH}$, soil texture, carbon and nitrogen content. The classification starts with bare sand, followed by vegetation dominated by Corynephorus canescens, Polytrichum piliferum, cup-lichens (and other smaller Cladonia spp.), Campylopus introflexus, reindeer lichens (and other larger Cladonia spp.), grass-dominated vegetation and heath (Fig. 1). Hasse (2005) showed that accumulation of soil organic matter was the main factor driving succession, covariating with $\mathrm{pH}$ and nitrogen $(\mathrm{N})$ content.

Apart from the total $\mathrm{N}$ stocks, no extensive data exist on the plant-availability of nutrients in drift sands. 


\begin{tabular}{|c|c|c|c|c|c|c|}
\hline \multicolumn{2}{|c|}{ sand } & \multicolumn{4}{|c|}{ pioneer vegetation } & \multirow{3}{*}{$\begin{array}{l}\text { dwarf } \\
\text { shrubs }\end{array}$} \\
\hline \multirow{2}{*}{ bare sand } & \multirow{2}{*}{$\begin{array}{l}\text { Coryn- } \\
\text { ephorus } \\
\text { (grass) }\end{array}$} & \multirow{2}{*}{$\begin{array}{l}\text { Polytrichum } \\
\text { (moss) }\end{array}$} & smaller lichens & \multirow{2}{*}{$\begin{array}{l}\text { reindeer } \\
\text { lichens }\end{array}$} & \multirow{2}{*}{ grasses } & \\
\hline & & & $\begin{array}{l}\text { Campylopus } \\
\text { (moss) }\end{array}$ & & & \\
\hline
\end{tabular}

Fig. 1 Vegetation succession scheme in inland dunes derived from Hasse (2005). Primary stages include bare sand, pioneer vegetation and Calluna dwarf shrub heath

Elements, such as $\mathrm{P}$, base cations or $\mathrm{Al}$ are important for plant growth. $\mathrm{P}$ is a major plant nutrient and, like $\mathrm{N}$, affected by cycling of organic matter and soil chemical conditions (Kooijman et al. 1998; Kooijman et al. 2009). Base cations $\left(\mathrm{Ca}^{2+}, \mathrm{K}^{+}, \mathrm{Mg}^{2+}\right.$ and $\left.\mathrm{Na}^{+}\right)$are also important, as they may selectively be taken up by the vegetation (Moszynska 1991; Smit et al. 2002) and decrease with the drop in $\mathrm{pH}$ during succession. A lower soil $\mathrm{pH}$ may also lead to an increase in $\mathrm{Al}^{3+}$ concentrations and $\mathrm{Al}: \mathrm{Ca}$ ratios causing potentially toxic conditions to the vegetation (Tietema 1992; de Graaf et al. 1997; van den Berg et al. 2005a; Bowman et al. 2008).

Acidification may reflect a loss of acid-neutralizing capacity of the soil, due to exchange of base cations $\left(\mathrm{Ca}^{2+}, \mathrm{K}^{+}, \mathrm{Mg}^{2+}, \mathrm{Na}^{+}\right)$for protons from plant roots and microorganisms. Other causes are atmospheric deposition of protons and proton producing substances, such as sulphur in the past (Bleeker and Erisman 1996; Eerens and van Dam 2001) and nitrogen compounds in past and present, particularly ammonium, which causes soil acidification after nitrification (van Breemen et al. 1983). Elevated nitrogen deposition may thus cause a lower soil $\mathrm{pH}$, displacement and leaching of base cations and an increase in acid cations, such as $\mathrm{Al}^{3+}$.

The aim of this paper was to further explore the development of nutrient and base status during succession and the impact of atmospheric deposition in inland dunes. The research questions were: 1) How do vegetation and soil change during succession? 2) How are soil parameters and species abundance affected by atmospheric nitrogen deposition? To answer these questions, vegetation relevés (containing a species list per plot and general plot parameters) and soil samples were collected throughout The Netherlands, divided over several succession stages and within a pronounced gradient in atmospheric nitrogen deposition, which allowed testing for both succession stage and nitrogen deposition.

\section{Materials and methods}

A field survey was conducted in 21 drift sand areas, distributed over the main cover sand regions (Drenthe, Veluwe, Utrecht, Brabant and river dunes along the Meuse; Fig. 2). In the 21 drift sand areas, a set of 165 relevés of random $1 \mathrm{~m}^{2}$ plots has been selected, stratified over eight different succession stages (Fig. 1) representing the chronosequence from bare sand to dry heath. The succession stages are derived from Hasse (2005) but are named after the dominant species: $1=$ bare sand $(n=24) ; 2=$ bare sand with tufts of Corynephorus canescens $(n=5) ; 3=$ mats of Polytrichum piliferum $(n=22), 4=$ vegetation dominated by small lichens $(n=38) ; 5=$ mats of Campylopus introflexus $(n=24)$ and $6=$ vegetation with reindeer lichens $(n=28)$. These six succession stages were extended with $7=$ grassland, i.e. vegetation with $>25 \%$ grasses, also containing some lichens and bryophytes $(n=9)$ and $8=$ dry heath with $>25 \%$ cover of Calluna vulgaris $(n=15)$.

For each of the 165 relevés, the vegetation structure was described: height and cover of the different plant types (vascular plants, cryptogams), bare sand and litter. Nomenclature of vascular plants follows van der Meijden (2005), lichens Aptroot et al. (2004), and bryophytes Siebel and During (2006). On mineral soil, in the Corynephorus stage, over 22 algal taxa can potentially be found (Prach et al. 1993), but in this study only the dominant species were surveyed, i.e. Klebsormidium spp (on bare sand poor in organic matter), Zygogonium ericetorum (on bare mineral soil rich in organic matter) and Palmogloea protuberans (on litter).

In each of the 165 plots, thickness of the $A_{h}$ was measured, and relative root biomass estimated in three classes $(1=$ low, $2=$ intermediate and $3=$ high amounts of roots visible in soil samples). Also, the upper $5 \mathrm{~cm}$ of the mineral soil was sampled, combining three subsamples of $100 \mathrm{~cm}^{3}$ for analysis 
Fig. 2 Map of the Netherlands showing the five main sand and inland dune areas with indication of investigated sites $(A$ Aekinge, $D$ Drouwen, $K$ Kootwijk, $W$ Wekerom) and regions mentioned in the text

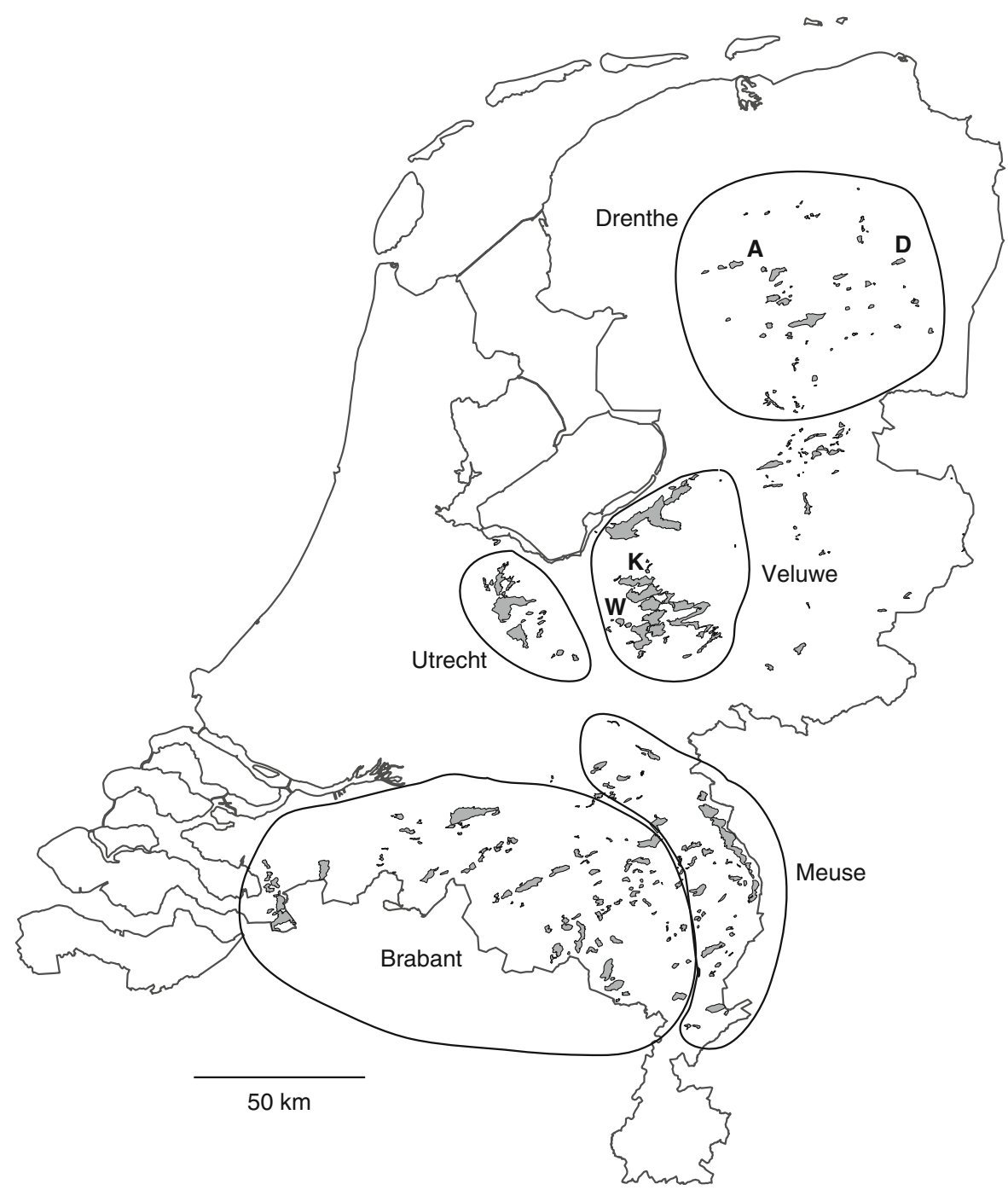

of water-extractable nutrients and base cations, which is considered a good measure for plant nutrient availability. Soil samples were dried at $70^{\circ} \mathrm{C}$ for $48 \mathrm{~h}$ and weighted to estimate the bulk density. Sieved and homogenized samples were shaken in purified water using a soil:water ratio of 1:2.5. The water extract was filtered over a $0.2 \mu \mathrm{m}$ membrane. Dissolved organic carbon (DOC), water-soluble phosphate and nitrogen compounds $\left(\mathrm{NH}_{4}{ }^{+}, \mathrm{NO}_{3}{ }^{-}\right)$were measured using an Auto Analyzer III (Bran+Luebbe). Cation concentrations were measured with an inductively coupled plasma analyzer (Fisher Iris Intrepid II). Additionally the $\mathrm{pH}\left(\mathrm{H}_{2} \mathrm{O}\right)$ and conductivity $\left(\mathrm{EC}_{25}\right)$ were measured.

The 165 soil samples were also used to analyze the effect of atmospheric deposition on soil parameters.
Atmospheric $\mathrm{N}$ deposition was derived from modelled data, based on emissions in 2004 (de Haan et al. 2008), and ranged from 21 to $47 \mathrm{~kg} \mathrm{ha}^{-1}$ year $^{-1}$. The median value, based on the average $\mathrm{N}$ deposition per site was $30 \mathrm{~kg} \mathrm{ha}^{-1}$ year $^{-1}$, which was also found to be a critical level for effects on the vegetation (Sparrius and Kooijman 2011). The dataset was split into 69 samples in sites with low deposition, i.e. values below the median value of $\mathrm{N}$ deposition, and 96 samples with high deposition. In low and high $\mathrm{N}$ deposition areas, distribution of samples over succession stages was more or less the same (chi-square test; $P>0.05$ ). However, vegetation with small lichens occurred more often in low-deposition sites, whereas large lichen vegetation were more common in highdeposition sites. In order to test whether soil 
parameters were affected by high atmospheric deposition of ammonium or, in the past, $\mathrm{SO}_{\mathrm{x}}$, values for each stage of succession were calculated for sites with high and lower $\mathrm{N}$ deposition values. High $\mathrm{N}$ deposition may affect $\mathrm{NH}_{4}: \mathrm{NO}_{3}$ and $\mathrm{Al}: \mathrm{Ca}$ ratios. $\mathrm{Al}: \mathrm{Ca}$ ratios above 2 are regarded as a critical level for aluminium toxicity for some plants (de Graaf et al. 1997). Apart from the $\mathrm{Al}: \mathrm{Ca}$ ratio, the $\mathrm{Al}:(\mathrm{Al}+\mathrm{Ca})$ ratio was used, which reduces the variation in the $\mathrm{Al}$ : $\mathrm{Ca}$ ratio when dividing by relative low values of $\mathrm{Ca}$.

A two-way ANOVA was used to test for differences between succession stages, and between high and low $\mathrm{N}$ deposition sites, with stage of succession and $\mathrm{N}$ deposition as independent parameters. A one-way ANOVA was used to test for significant differences between high and low deposition sites within a particular succession stage. Significant effects $(P<0.05)$ of $\mathrm{N}$ deposition on occurrence of particular plant species were tested with a chi-square test for species having at least 15 occurrences in the data set and being $25 \%$ more abundant in one group compared to the other.

\section{Results}

Species composition

Vegetation cover and height increased during succession (Table 1). In the first stage, vegetation cover was only $9 \%$, but cover gradually increased to $99 \%$ during succession. Algae and bryophytes dominated in early succession stages, whereas vascular plants, dwarf shrubs and lichens had the highest cover in older stages. The tall grass Ammophila arenaria is sometimes present in the Corynephorus stage as a relic from earlier times, when the species was planted as an erosion prevention measure. Vegetation height increased from 4 up to $27 \mathrm{~cm}$. In early stages, cover of algae was higher than in later stages. Cryptogam cover gradually increased, but was at its highest in the two lichen-dominated stages. Algae showed their optimum cover in the Corynephorus stage.

Total species density increased during succession, but some of the species groups showed distinct optima. Highest bryophyte diversity was found in the last stages and includes most liverworts, which were present in shaded niches within Agrostis vinealis-dominated grassland and sparse Calluna vegetation. Lichen diversity had its optimum in lichen vegetation with substrate lichens, which are generally smaller species. Nevertheless, lichens formed an important contribution of plant diversity in almost all stages. In lichendominated stages, lichens contributed to $52-62 \%$ of species richness, but in other stages, contribution of lichens still ranged from $23 \%$ to $44 \%$. Many species depend on the presence of patches of bare mineral soil. Total species density was also highest in the stage with smaller Cladonia species. Larger reindeer lichens occurred in older, taller pioneer vegetation that was already somewhat encroached by grasses. Vascular plant density was highest in the oldest succession stages. In the first succession stages, diversity was mainly due to grasses. In older stages, more and more herbs were present.

The species recorded in the relevés are presented in Table 2, ordered by their optimum succession stage. A separate group of indicator species was made for taxa occurring in a maximum of three stages. In the bare sand and Corynephorus stages, the vegetation consisted of single tussocks of $C$. canescens in bare sand, with the sand grains often stuck together by algal filaments of Klebsormidium sp. An indicator species present on patches of bare sand was the lichen Stereocaulon condensatum. Over time, the space between the tussocks of Corynephorus canescens became filled up by the bryophyte Polytrichum piliferum. The moss mat still had an open structure, with sand visible between the individual shoots. Eventually, most of the space became filled up with sparse grasses like Agrostis vinealis, but especially with small lichen species, such as Cladonia coccifera, C. ramulosa and $C$. grayi. In the stage with Campylopus introflexus, which also established in the Polytrichum moss mat, many lichen species may still occur, even though lichen diversity had clearly dropped and smaller species were generally lacking.

Most vegetation parameters clearly differed between succession stages, but not between areas with low and high $\mathrm{N}$ deposition. However, significant effects of atmospheric $\mathrm{N}$ deposition were found for cover of algae, total number of species and number of lichen species (Table 3). Cover of algae was generally two times higher in areas with high $\mathrm{N}$ deposition. At high $\mathrm{N}$ deposition, total species number was lower in almost all succession stages than at low $\mathrm{N}$ deposition. Number of lichen species also significantly decreased at high $\mathrm{N}$ deposition, especially in the stage with small lichens. 
Table 1 The eight succession stages and vegetation characteristics showing means and standard deviations. A two-way ANOVA was performed to test for differences between succession stages $(* P<0.05)$

\begin{tabular}{|c|c|c|c|c|c|c|c|c|}
\hline & Bare sand & Corynephorus & Polytrichum & $\begin{array}{l}\text { Smaller } \\
\text { lichens }\end{array}$ & Campylopus & $\begin{array}{l}\text { Reindeer } \\
\text { lichens }\end{array}$ & Grasses & $\begin{array}{l}\text { Dwarf } \\
\text { shrubs }\end{array}$ \\
\hline Number of plots & 24 & 5 & 22 & 38 & 24 & 28 & 9 & \\
\hline \multicolumn{9}{|l|}{ Vegetation structure } \\
\hline Height shrubs $(\mathrm{cm})^{*}$ & $0.0(0.0)$ & $0.0(0.0)$ & $0.5(2.5)$ & $1.3(4.6)$ & $6.3(15)$ & $8.2(25)$ & $2.2(6.6)$ & $21(13)$ \\
\hline Height vascular plants $(\mathrm{cm})^{*}$ & $4.0(12)$ & $14(8.0)$ & $18(12)$ & $17(9.0)$ & $18(9.0)$ & $26(10)$ & $27(11)$ & $26(14)$ \\
\hline Height cryptogams $(\mathrm{cm})^{*}$ & $0.0(0.0)$ & $0.2(0.4)$ & $1.9(1.6)$ & $2.6(0.9)$ & $2.7(0.9)$ & $4.4(1.2)$ & $2.8(1.2)$ & $3.1(1.0)$ \\
\hline Cover bare sand $(\%)^{*}$ & $91(22)$ & $76(11)$ & $15(15)$ & $6.0(8.0)$ & $4.0(6.0)$ & $2.0(4.0)$ & $1.0(1.0)$ & $7.0(8.0)$ \\
\hline Cover litter $(\%)^{*}$ & $0.1(0.3)$ & $1.6(1.9)$ & $0.9(1.4)$ & $3.3(6.8)$ & $5.0(6.0)$ & $12(16)$ & $18(31)$ & $14(21)$ \\
\hline Cover vascular plants $(\%)^{*}$ & $3.0(7.4)$ & $18(12)$ & $14(8.0)$ & $23(14)$ & $16(12)$ & $27(17)$ & $57(29)$ & $18(16)$ \\
\hline Cover bryophytes $(\%)^{*}$ & $0.0(0.0)$ & $4.2(8.8)$ & $60(30)$ & $47(31)$ & $76(16)$ & $25(27)$ & $32(26)$ & $51(30)$ \\
\hline Cover lichens $(\%)^{*}$ & $0.0(0.0)$ & $0.0(0.0)$ & $7.0(18)$ & $31(20)$ & $7.7(11)$ & $43(27)$ & $22(29)$ & $13(10)$ \\
\hline Cover algae $(\%)^{*}$ & $23(38)$ & $62(21)$ & $19(23)$ & $14(20)$ & $8.0(20)$ & $3.0(7)$ & $10(19)$ & $12(18)$ \\
\hline \multicolumn{9}{|l|}{ Species densities $\left(\mathrm{n} \mathrm{m}^{-2}\right)$} \\
\hline All species* & $0.6(0.4)$ & $3.7(0.4)$ & $6.0(2.4)$ & $15(4.5)$ & $10(3.5)$ & $10(3.2)$ & $9.8(3.1)$ & $11(3.2)$ \\
\hline Algae* & $0.4(0.5)$ & $0.7(0.0)$ & $1.0(0.5)$ & $1.1(0.6)$ & $0.6(0.6)$ & $0.4(0.6)$ & $0.6(0.5)$ & $0.9(0.7)$ \\
\hline Bryophytes* & - & $0.3(0.5)$ & $1.4(0.6)$ & $1.6(1.3)$ & $1.8(0.6)$ & $1.7(0.7)$ & $2.0(1.3)$ & $1.8(1.2)$ \\
\hline Lichens* & - & $0.9(0.0)$ & $1.4(0.0)$ & $9.3(3.8)$ & $4.4(3.1)$ & $5.2(2.4)$ & $3.0(2.3)$ & $4.1(0.9)$ \\
\hline Macrofungi & - & - & $0.0(0.2)$ & $0.0(0.2)$ & - & $0.0(0.2)$ & - & $0.1(0.3)$ \\
\hline Vascular plants* & $0.3(0.5)$ & $1.9(0.5)$ & $2.0(1.1)$ & $3.2(1.6)$ & $3.3(1.5)$ & $3.0(1.4)$ & $4.2(1.6)$ & $4.2(1.9)$ \\
\hline
\end{tabular}

Few individual species showed a response to $\mathrm{N}$ deposition (Table 4). The lichens Cetraria aculeata and Cladonia floerkeana, species characteristic for early succession stages, and the perennial herb Hypochaeris radicata, characteristic for late succession stages were species that had significantly higher frequency in low-deposition sites. Several species were more abundant in high-deposition sites, including species from late succession stages (Cladonia gracilis, C. zopfii), species from substrates rich in organic matter (C. macilenta, C. ramulosa, Dicranum scoparium), an annual herb from early succession stages (Spergula morisonii), a graminoid (Carex arenaria) and seedlings of trees (Pinus sylvestris).

\section{Soil characteristics}

During succession, thickness of the $A_{h}$ increased from zero to approximately $7 \mathrm{~cm}$, and bulk density and $\mathrm{pH}$ decreased (Table 5). Along with the decrease in $\mathrm{pH}$, the amounts of water-extractable $\mathrm{Fe}, \mathrm{Al}$ and $\mathrm{S}$ in the topsoil increased, as well as $\mathrm{Al}: \mathrm{Ca}$ ratio. Base cation concentrations were two to three times higher in late succession stages compared to open sand and Corynephorus, despite the decrease in $\mathrm{pH}$. Divalent cations such as $\mathrm{Ca}$ and $\mathrm{Mg}$ occurred in lower quantities in water extracts than monovalent cations like $\mathrm{Na}$ and $\mathrm{K}$, which can be regarded as a side effect of the use of water instead of extraction with a salt solution. Also water-extractable ammonium, nitrate and phosphate both increased during succession, as well as the $\mathrm{NH}_{4}: \mathrm{NO}_{3}$ ratio.

Most soil parameters clearly changed during succession, but did not differ between areas with low and high atmospheric $\mathrm{N}$ deposition. However, $\mathrm{NH}_{4}: \mathrm{NO}_{3}$ ratio, $\mathrm{pH}$ and $\mathrm{Al}:(\mathrm{Al}+\mathrm{Ca})$ ratio were indeed affected by $\mathrm{N}$ deposition (Table 6). $\mathrm{NH}_{4}: \mathrm{NO}_{3}$ ratio was significantly higher at high $\mathrm{N}$ deposition, especially in later stages of succession. Soil $\mathrm{pH}$ decreased with $0.1-0.3$ units in sites with high atmospheric deposition. Also, $\mathrm{Al}: \mathrm{Al}+\mathrm{Ca}$ ratio was significantly higher at high $\mathrm{N}$ deposition. The $\mathrm{Al}: \mathrm{Ca}$ ratio was consistently $0.2-0.9$ units lower in the lowdeposition sites, but the difference was not significant.

\section{Discussion}

Vegetation succession

The clear increase in vegetation cover and changes in species composition during succession were in accord 
Table 2 The eight succession stages and their species composition. Species order reflects their appearance during succession. Indicator species are species restricted to a maximum of three succession stages. Plant type: A(lgae), B(ryophytes), L(ichens) and (V)ascular plants. A two-way ANOVA was performed to test for differences between succession stages $(* P<0.05)$

\begin{tabular}{|c|c|c|c|c|c|c|c|c|c|}
\hline \multirow[t]{3}{*}{ Plant type } & & Bare sand & Corynephorus & Polytrichum & Smaller & Campylopus & Reindeer & Grasses & \multirow{2}{*}{$\begin{array}{l}\text { Dwarf } \\
\text { shrubs } \\
15\end{array}$} \\
\hline & Number of plots & 25 & 7 & 23 & 39 & 26 & 28 & 10 & \\
\hline & Common species & $\begin{array}{l}\text { Occurrence } \\
\text { in plots }(\%)\end{array}$ & & & & & & & \\
\hline $\mathrm{V}$ & Corynephorus canescens & 16 & 86 & 83 & 85 & 77 & 39 & 50 & 20 \\
\hline A & Klebsormidium sp. & 36 & 71 & 35 & 31 & 12 & 7 & & 33 \\
\hline V & Carex arenaria & 8 & & 9 & 5 & 15 & 18 & 20 & 20 \\
\hline B & Polytrichum piliferum & & 29 & 96 & 87 & 69 & 54 & 30 & 40 \\
\hline $\mathrm{V}$ & Rumex acetosella & & & 4 & 23 & 31 & 43 & 30 & 27 \\
\hline V & Spergula morisonii & & & 26 & 31 & 42 & 7 & 20 & 13 \\
\hline A & Zygogonium ericetorum & & & 13 & 5 & 4 & 4 & & 13 \\
\hline B & Ceratodon purpureus & & & 4 & 3 & 4 & & 10 & 7 \\
\hline A & Palmogloea protuberans & & & 52 & 77 & 46 & 32 & 60 & 40 \\
\hline V & Hypochaeris radicata & & & 9 & 10 & 8 & 7 & 20 & 13 \\
\hline B & Campylopus introflexus & & & 30 & 46 & 96 & 32 & 20 & 40 \\
\hline $\mathrm{L}$ & Cladonia coccifera & & & 57 & 92 & 73 & 50 & 40 & 73 \\
\hline V & Agrostis vinealis & & 14 & 39 & 62 & 42 & 46 & 40 & 40 \\
\hline $\mathrm{L}$ & Cladonia ramulosa & & & 13 & 69 & 35 & 57 & 30 & 53 \\
\hline $\mathrm{L}$ & Cladonia subulata & & & 9 & 18 & 23 & 21 & & 20 \\
\hline $\mathrm{L}$ & Cladonia floerkeana & & & 4 & 36 & 15 & 7 & 10 & 13 \\
\hline $\mathrm{L}$ & Cladonia glauca & & & 4 & 41 & 15 & 7 & 20 & 13 \\
\hline $\mathrm{L}$ & Cladonia arbuscula & & 14 & & 28 & 8 & 25 & 10 & 7 \\
\hline $\mathrm{L}$ & Cladonia crispata & & & & 46 & 15 & 18 & 10 & 7 \\
\hline $\mathrm{L}$ & Cladonia uncialis & & 14 & & 51 & 19 & 29 & & 7 \\
\hline $\mathrm{L}$ & Cladonia zopfii & & & & 41 & 19 & 14 & 10 & 7 \\
\hline $\mathrm{L}$ & Cladonia furcata & & & 4 & 10 & & 29 & 40 & 13 \\
\hline $\mathrm{L}$ & Cladonia macilenta & & & 4 & 38 & 31 & 14 & 20 & 20 \\
\hline $\mathrm{L}$ & Cladonia portentosa & & & 4 & 46 & 23 & 93 & 40 & 27 \\
\hline $\mathrm{L}$ & Cladonia grayi & & & 13 & 51 & 42 & 43 & 50 & 40 \\
\hline $\mathrm{L}$ & Placynthiella icmalea & & & & 5 & 4 & 7 & 20 & 20 \\
\hline V & Pinus sylvestris (seedlings) & & & & 13 & & 21 & 10 & 20 \\
\hline $\mathrm{L}$ & Cladonia pulvinata & & & & 21 & 4 & 4 & & 7 \\
\hline V & Festuca filiformis & & & 9 & 49 & 38 & 32 & 70 & 13 \\
\hline $\mathrm{V}$ & Calluna vulgaris & & & 4 & 10 & 19 & 18 & 10 & 93 \\
\hline $\mathrm{V}$ & Deschampsia flexuosa & & & 4 & 18 & 19 & 46 & 50 & 47 \\
\hline B & Hypnum jutlandicum & & & 4 & 3 & 4 & 21 & 20 & 27 \\
\hline \multirow[t]{2}{*}{ B } & Dicranum scoparium & & & & 18 & 8 & 50 & 60 & 33 \\
\hline & Indicator species & & & & & & & & \\
\hline $\mathrm{V}$ & Ammophila arenaria & 4 & & 9 & & & & & \\
\hline $\mathrm{L}$ & Placynthiella uliginosa & & 14 & & 10 & & & & 13 \\
\hline V & Salix repens & & & 4 & & & & & \\
\hline $\mathrm{L}$ & Stereocaulon condensatum & & & 13 & 8 & 4 & & & \\
\hline $\mathrm{L}$ & Diploschistes muscorum & & & & 10 & 4 & & & \\
\hline $\mathrm{L}$ & Cetraria aculeata & & 14 & & 46 & 12 & 4 & & 7 \\
\hline $\mathrm{L}$ & Cladonia borealis & & & & 31 & 12 & & & 7 \\
\hline
\end{tabular}


Table 2 (continued)

\begin{tabular}{|c|c|c|c|c|c|c|c|c|c|}
\hline \multirow[t]{2}{*}{ Plant type } & & Bare sand & Corynephorus & Polytrichum & Smaller & Campylopus & Reindeer & Grasses & Dwarf \\
\hline & Number of plots & 25 & 7 & 23 & 39 & 26 & 28 & 10 & 15 \\
\hline $\mathrm{L}$ & Cladonia cervicornis & & 14 & & 41 & 19 & 11 & & \\
\hline $\mathrm{L}$ & Cladonia foliacea & & & 4 & 21 & 8 & 7 & & \\
\hline $\mathrm{L}$ & Cladonia gracilis & & & & 46 & 8 & 43 & & 7 \\
\hline $\mathrm{L}$ & Cladonia monomorpha & & & & 18 & 8 & & & 7 \\
\hline $\mathrm{L}$ & Cladonia phyllophora & & & & 5 & & & & \\
\hline $\mathrm{L}$ & Placynthiella oligotropha & & & & 3 & & & & \\
\hline $\mathrm{L}$ & Pycnothelia papillaria & & & & 3 & & & & \\
\hline B & Cephaloziella divaricata & & & & 3 & & & & \\
\hline $\mathrm{L}$ & Micarea lignaria & & & & 3 & & & & \\
\hline $\mathrm{L}$ & Cladonia strepsilis & & & & 31 & 8 & 7 & & \\
\hline $\mathrm{L}$ & Cladonia verticillata & & & & 13 & & & & \\
\hline $\mathrm{L}$ & Micarea leprosula & & & & 13 & 4 & & & 7 \\
\hline $\mathrm{L}$ & Stereocaulon saxatile & & & & 5 & 8 & & & \\
\hline $\mathrm{L}$ & Trapeliopsis granulosa & & 14 & & 8 & 8 & & & \\
\hline $\mathrm{L}$ & Cetraria islandica & & & & 15 & & 11 & & \\
\hline $\mathrm{L}$ & Cladonia ciliata & & & & 3 & & 11 & & \\
\hline V & Festuca ovina subsp. hirtula & & & & & 4 & & 10 & \\
\hline B & Ptilidium ciliare & & & & & & & 10 & \\
\hline V & Juncus squarrosus & & 14 & & & & & & 20 \\
\hline $\mathrm{V}$ & Filago minima & & & 4 & & & & & 7 \\
\hline $\mathrm{V}$ & Gnaphalium sylvaticum & & & & 3 & & & & 7 \\
\hline $\mathrm{V}$ & Teesdalia nudicaulis & & & & 3 & & & & 7 \\
\hline $\mathrm{V}$ & Jasione montana & & & & & & 4 & & 7 \\
\hline $\mathrm{V}$ & Nardus stricta & & & & 3 & & 11 & & 13 \\
\hline $\mathrm{V}$ & Galium saxatile & & & & & & & & 7 \\
\hline $\mathrm{L}$ & Baeomyces rufus & & & 9 & 3 & & 4 & & 13 \\
\hline $\mathrm{V}$ & Molinea coerulea & & & & 3 & 4 & & & 13 \\
\hline B & Polytrichum juniperinum & & & & & & 4 & 10 & 13 \\
\hline $\mathrm{V}$ & Empetrum nigrum & & & & & & & & 7 \\
\hline $\mathrm{V}$ & Juniperus communis & & & & & & & & 7 \\
\hline B & Lophozia ventricosa & & & & & & & & 7 \\
\hline B & Pohlia nutans & & & & & & & & 7 \\
\hline $\mathrm{V}$ & Scapania compacta & & & & & & & & 7 \\
\hline V & Thymus serpyllum & & & & & & & & 7 \\
\hline
\end{tabular}

with Hasse (2005). Succession started with bare sand, which is colonized by Corynephorus canescens, in active drift sands usually only after mild winters and wet summers (Riksen et al. 2008). Cover of algae was especially high in the Corynephorus succession stage, which agrees with previous studies (van den Ancker et al. 1985; Hasse 2005; Guo et al. 2008). In this stage, where the vegetation consists of single tussocks of $C$. canescens in bare sand, with the grains stuck together by algal filaments of Klebsormidium sp. Indicator species may be used for the assessment of habitat quality and site history (Ott 1978). The tall grass Ammophila arenaria may be seen as a relic from earlier times (c. 1850 to 1930) when the species was planted as an erosion prevention measure (van der Meijden 2005). As establishment of $A$. arenaria is restricted to bare sand (van der Putten et al. 1993), it is now a good indicator of sites that have not been 
Table 3 Significant effects of $\mathrm{N}$ deposition on vegetation characteristics in sites with relatively low $\left(<30 \mathrm{~kg} \mathrm{~N} \mathrm{ha}^{-1}\right.$ year $\left.^{-1}\right)$ and high atmospheric $\mathrm{N}$ deposition. Means $(n=2-22)$ and standard deviations. *significant difference between high and low deposition sites in all succession stages (two-way ANOVA). **significant difference between high and low deposition sites within a succession stage (one-way ANOVA)

\begin{tabular}{|c|c|c|c|c|c|c|c|c|}
\hline & $\mathrm{N}$ deposition & Corynephorus & Polytrichum & $\begin{array}{l}\text { Smaller } \\
\text { lichens }\end{array}$ & Campylopus & $\begin{array}{l}\text { Reindeer } \\
\text { lichens }\end{array}$ & Grasses & $\begin{array}{l}\text { Dwarf } \\
\text { shrubs }\end{array}$ \\
\hline \multirow[t]{2}{*}{ Cover of algae* $(\%)$} & Low & $17(31)$ & $15(25)$ & $7(7) * *$ & $2(2)$ & $4(6)$ & $5(7)$ & $6(7)$ \\
\hline & High & $39(42)$ & $23(23)$ & $25(27)$ & $13(26)$ & $4(8)$ & $12(22)$ & $20(25)$ \\
\hline \multirow[t]{2}{*}{ Total plant species* } & Low & $1(1)$ & $7(3)$ & $17(5) * *$ & $11(4)$ & $11(5)$ & $10(4)$ & $10(4)$ \\
\hline & High & $1(1)$ & $6(2)$ & $14(3)$ & $10(3)$ & $10(3)$ & $10(3)$ & $12(2)$ \\
\hline \multirow[t]{2}{*}{ Lichen species* } & Low & $0(0)$ & $2(2)$ & $10(4) * *$ & $5(3)$ & $5(3)$ & $4(1)$ & $3(2)$ \\
\hline & high & $0(0)$ & $1(1)$ & $8(3)$ & $4(3)$ & $5(2)$ & $3(3)$ & $5(3)$ \\
\hline
\end{tabular}

covered by vegetation over the past $80-160$ years. Another indicator species present on bare sand is the lichen Stereocaulon condensatum, a lichen containing cyanobacteria in addition to green algae, which enable nitrogen fixation, supporting findings by Sparrius (2011) that the early stages of pioneer vegetation are strongly $\mathrm{N}$ limited.

Over time, the space between the tussocks of Corynephorus canescens becomes filled up by the moss Polytrichum piliferum, which creates a uniform $\mathrm{A}_{\mathrm{h}}$ horizon consisting of moss rhizoids (Bowden 1991). The moss mat has an open structure, with sand still visible between the individual shoots. Splash erosion is an important factor to maintain open sand, especially on slopes (Riksen and Goossens 2007), which reduces colonization by other species and may

Table 4 Significant effects of $\mathrm{N}$ deposition on individual species presence as $\%$ of sites with relatively low $\left(<30 \mathrm{~kg} \mathrm{~N} \mathrm{ha}^{-1}\right.$ year $\left.^{-1}\right)$ and higher atmospheric $\mathrm{N}$ deposition

\begin{tabular}{lcc}
\hline Species & Low N & High N \\
\hline Cetraria aculeata & 20 & 7 \\
Cladonia floerkeana & 20 & 10 \\
Hypochaeris radicata & 17 & 4 \\
Carex arenaria & 3 & 21 \\
Cladonia gracilis & 13 & 24 \\
Cladonia macilenta & 16 & 23 \\
Cladonia ramulosa & 29 & 47 \\
Cladonia zopfii & 13 & 19 \\
Dicranum scoparium & 17 & 24 \\
Pinus sylvestris (seedlings) & 7 & 10 \\
Spergula morisonii & 17 & 26 \\
\hline
\end{tabular}

favour the development of highly adapted species characteristic of the smaller lichen vegetation. Eventually, most of the space between the individual $P$. piliferum shoots becomes filled up with small lichen species and sparse grasses, especially tussocks of Festuca species in addition to Corynephorus canescens. In accord with Hasse (2005), the first lichens in this stage are primarily species that usually produce fungal spores (Cladonia coccifera and $C$. grayi) and fine soralia or fragments (Cladonia glauca and $C$. macilenta). Observations show that species with larger diaspores settle later, e.g. Cladonia borealis, $C$. strepsilis and volume lichens, i.e. species with a shrub-like, reindeer lichen habit such as $C$. arbuscula, C. portentosa and C. zopfii. This general increase in size in individual lichen thalli may be related to water retention in the topsoil and transpiration of the vegetation, causing a milder microclimate (Biermann and Daniëls 1997; Bültmann and Daniëls 2001).

Since its introduction in the 1960s, the exotic, invasive moss Campylopus introflexus establishes between Polytrichum piliferum shoots as well (Sparrius and Kooijman 2011). In contrast to the smaller lichens, Campylopus introflexus is a strong competitor, especially as it forms an ectorganic layer of several $\mathrm{cm}$. This ectorganic layer, the decaying lower part of the moss shoots, improves $\mathrm{N}$ mineralization and nutrient cycling (Sparrius 2011). Conversely, most lichens form only a thin mat, incapable of competing with taller species. Campylopus introflexus is predominantly present in sites with high $\mathrm{N}$ deposition (Sparrius and Kooijman 2011) and usually forms a uniform moss mat up to $5 \mathrm{~cm}$ high. However, under low $\mathrm{N}$ deposition, reindeer lichen species may become dominant, and form a succession stage that may last 
Table 5 The eight succession stages and their soil characteristics. A Kruskal-Wallis test was performed to test for differences between succession stages $(* P<0.05)$

\begin{tabular}{|c|c|c|c|c|c|c|c|c|}
\hline Number of plots & Bare sand & Corynephorus & Polytrichum & $\begin{array}{l}\text { Smaller } \\
\text { lichens } \\
38\end{array}$ & Campylopus & $\begin{array}{l}\text { Reindeer } \\
\text { lichens } \\
28\end{array}$ & Grasses & $\begin{array}{l}\text { Dwarf } \\
\text { shrubs } \\
15\end{array}$ \\
\hline Soil parameters & \multicolumn{8}{|c|}{ Means and standard deviations } \\
\hline $\mathrm{A}_{\mathrm{h}}$ solum depth $(\mathrm{cm}) *$ & $0.2(1.0)$ & $0.0(0.0)$ & $1.0(1.0)$ & $5.9(3.5)$ & $4.0(2.1)$ & $6.8(4.1)$ & $7.0(4.7)$ & $6.4(4.4)$ \\
\hline Soil bulk density $\left(\mathrm{g} \mathrm{cm}^{-3}\right) *$ & $1.3(0.1)$ & $1.2(0.1)$ & $1.1(0.2)$ & $0.9(0.2)$ & $1.0(0.2)$ & $0.8(0.1)$ & $0.6(0.2)$ & $0.8(0.2)$ \\
\hline Relative root biomass in $A_{h}(1-3) *$ & $0.0(0.2)$ & $0.4(0.5)$ & $0.6(0.7)$ & $1.3(0.6)$ & $0.8(0.6)$ & $1.6(0.6)$ & $1.5(0.7)$ & $1.5(0.5)$ \\
\hline $\mathrm{pH}\left(\mathrm{H}_{2} \mathrm{O}\right) *$ & $4.9(0.4)$ & $5.2(0.5)$ & $4.9(0.3)$ & $4.5(0.3)$ & $4.5(0.3)$ & $4.3(0.3)$ & $4.2(0.5)$ & $4.6(0.5)$ \\
\hline Conductivity $\mathrm{EC}_{25} *$ & $16(4.0)$ & $14(2.0)$ & $21(7.0)$ & $35(15)$ & $44(40)$ & $54(15)$ & $96(46)$ & $54(33)$ \\
\hline \multicolumn{9}{|l|}{ Soil chemistry (water-extractable) } \\
\hline \multicolumn{9}{|l|}{ Acid cations $\left(\mathrm{mmol} \mathrm{m}^{-2}\right)$} \\
\hline $\mathrm{Al} *$ & $1.3(1.1)$ & $0.5(0.2)$ & $2.0(0.9)$ & $2.8(1.4)$ & $3.4(1.6)$ & $4.2(1.7)$ & $4.5(1.8)$ & $3.8(2.6)$ \\
\hline $\mathrm{Fe} *$ & $0.2(0.2)$ & $0.0(0.0)$ & $0.3(0.2)$ & $0.8(0.4)$ & $0.9(0.6)$ & $1.1(0.5)$ & $1.0(0.9)$ & $1.0(0.7)$ \\
\hline $\mathrm{S}_{\mathrm{tot}} *$ & $4.2(1.5)$ & $4.1(1.4)$ & $4.7(1.5)$ & $5.2(2.7)$ & $6.1(3.6)$ & $7.0(2.8)$ & $9.7(4.5)$ & $6.8(4.4)$ \\
\hline $\mathrm{Al}: \mathrm{Ca}$ ratio $*$ & $1.8(1.4)$ & $0.7(0.3)$ & $2.0(0.9)$ & $2.2(0.9)$ & $2.5(0.9)$ & $2.4(1.0)$ & $2.1(1.8)$ & $2.3(2.2)$ \\
\hline \multicolumn{9}{|l|}{ Base cations $\left(\mathrm{mmol} \mathrm{m}{ }^{-2}\right)$} \\
\hline $\mathrm{Ca} *$ & $0.8(0.2)$ & $0.8(0.2)$ & $1.1(0.3)$ & $1.3(0.8)$ & $1.5(1.1)$ & $1.9(0.7)$ & $2.5(1.1)$ & $2.3(2.5)$ \\
\hline $\mathrm{K} *$ & $2.3(1.5)$ & $3.7(2.5)$ & $4.9(2.1)$ & $4.8(2.4)$ & $5.0(2.8)$ & $7.1(2.2)$ & $8.9(2.3)$ & $7.1(3.9)$ \\
\hline $\mathrm{Mg} *$ & $0.7(0.4)$ & $0.8(0.1)$ & $1.2(0.4)$ & $1.5(1.0)$ & $1.6(0.9)$ & $2.0(0.7)$ & $3.1(1.2)$ & $2.1(1.1)$ \\
\hline $\mathrm{Na} *$ & $3.8(2.0)$ & $3.0(1.2)$ & $6.5(3.0)$ & $6.7(3.2)$ & $7.9(3.9)$ & $7.2(2.0)$ & $8.7(3.1)$ & $8.5(3.6)$ \\
\hline Sum of base cations * & $7.7(3.6)$ & $8.5(3.6)$ & $14(4.7)$ & $15(5.8)$ & $16(7.4)$ & $18(4.4)$ & $23(6.4)$ & $20(8.1)$ \\
\hline \multicolumn{9}{|l|}{ Nutrients $\left(\mathrm{mmol} \mathrm{m}^{-2}\right)$} \\
\hline $\mathrm{NH}_{4}^{+} *$ & $1.0(1.4)$ & $0.1(0.2)$ & $0.8(0.9)$ & $2.2(2.4)$ & $3(4.6)$ & $6.1(5.2)$ & $12(17)$ & $9.1(20)$ \\
\hline $\mathrm{NO}_{3}^{-} *$ & $3.9(3.9)$ & $1.7(1.0)$ & $2.3(1.7)$ & $4.8(4.7)$ & 7.9 (13) & $5.3(4.9)$ & $7.9(7.0)$ & $5.9(12)$ \\
\hline $\mathrm{NH}_{4}$ as $\%$ of total $\mathrm{N} *$ & $20(21)$ & $6.0(14)$ & $23(24)$ & $28(23)$ & $22(20)$ & $52(28)$ & $54(21)$ & $42(39)$ \\
\hline $\mathrm{NH}_{4}: \mathrm{NO}_{3}$ ratio $*$ & $0.4(0.7)$ & $0.1(0.2)$ & $0.5(0.6)$ & $0.7(1.2)$ & $0.4(0.5)$ & $2.7(3.9)$ & $2.3(3.2)$ & $2.4(3.2)$ \\
\hline $\mathrm{PO}_{4}^{3-*}$ & $0.0(0.0)$ & $0.0(0.0)$ & $0.0(0.0)$ & $0.3(0.5)$ & $0.6(1.4)$ & $1.3(1.4)$ & $1.8(1.9)$ & $1.4(1.8)$ \\
\hline
\end{tabular}

for several decades, before turning into heath and forest (Sparrius 2011).

Both Campylopus and lichen vegetation are eventually invaded from below by stoloniferous grasses, mostly Agrostis vinealis and sometimes Carex arenaria. The vegetation then usually transforms into grassland, with a shorter or longer period in which reindeer lichen species dominate. In older stages, more and more herbs were present, many of which are indicators of well-buffered soils and primary occur in the Genisto anglicae-Callunetum association (Weeda et al. 1996).

At some sites, especially on gravel-rich blowouts and sometimes on sites with buried profiles Calluna vulgaris settles to form a mosaic with lichen vegetation. Apart from lower aeolian dynamics and more stable conditions for soil development, which allows the vegetation to grow faster, sites with a buried soil or a vertical transition of drift sand to more compact (peri)glacial deposits may also have improved growth conditions via higher water retention capacity as found by Bijlsma (2010) in forested drift sands. Such more humid places can be recognized in earlier succession stages by the presence of Juncus squarrosus, Molinea caerulea and Salix repens. The lifespan of species-rich lichen vegetation may be prolonged if Calluna growth and forest development is controlled by grazing and tree removal (Daniëls et al. 2008; Sparrius 2011).

Soil formation and nutrient availability during succession

In accord with Hasse (2005), soil organic matter increased during succession and the $\mathrm{pH}$ became lower as a result of the accumulation of soil organic matter. 
Table 6 Significant effects of $\mathrm{N}$ deposition on soil characteristics in sites with relatively low $\left(<30 \mathrm{~kg} \mathrm{~N} \mathrm{ha}^{-1}\right.$ year $\left.^{-1}\right)$ and higher atmospheric $\mathrm{N}$ deposition. Means $(n=2-22)$ and standard deviations. *significant difference between high and low deposition sites in all succession stages (two-way ANOVA), **significant difference between high and low deposition sites within a succession stage (one-way ANOVA)

\begin{tabular}{lllllllll}
\hline & N deposition & Corynephorus & Polytrichum & $\begin{array}{l}\text { Smaller } \\
\text { lichens }\end{array}$ & Campylopus & $\begin{array}{l}\text { Reindeer } \\
\text { lichens }\end{array}$ & $\begin{array}{c}\text { Grasses } \\
\text { Dwarf } \\
\text { shrubs }\end{array}$ \\
\hline $\mathrm{NH}_{4}: \mathrm{NO}_{3}$ ratio* $\left(\mathrm{mmol} \mathrm{mmol}^{-1}\right)$ & Low & $0.4(0.5)$ & $0.8(0.7) * *$ & $0.5(0.7)$ & $0.4(0.6)$ & $0.8(0.7)$ & $0.6(0.1)$ & $2.1(2.0)$ \\
& High & $0.4(0.7)$ & $0.3(0.5)$ & $1.0(1.6)$ & $0.5(0.4)$ & $3.2(4.2)$ & $2.8(3.6)$ & $2.7(4.0)$ \\
$\mathrm{pH}^{*}$ & Low & $5.0(0.4)$ & $5.0(0.1)$ & $4.7(0.4) * *$ & $4.5(0.5)$ & $4.6(0.6) * *$ & $4.3(0.3)$ & $4.7(0.7)$ \\
& High & $5.0(0.5)$ & $4.9(0.4)$ & $4.4(0.2)$ & $4.5(0.3)$ & $4.3(0.2)$ & $4.3(0.6)$ & $4.5(0.4)$ \\
$\mathrm{Al}: \mathrm{Al}+\mathrm{Ca}$ ratio $*\left(\mathrm{mmol} \mathrm{mmol}^{-1}\right)$ & Low & $48(22) * *$ & $63(11)$ & $66(11)$ & $66(10)$ & $64(6)$ & $58(4)$ & $60(20)$ \\
& High & $57(15)$ & $65(10)$ & $68(6)$ & $70(8)$ & $70(8)$ & $65(13)$ & $67(11)$ \\
$\mathrm{Al}: \mathrm{Ca}$ ratio $\left(\mathrm{mmol} \mathrm{mmol}^{-1}\right)$ & Low & $1.4(1.4) * *$ & $1.9(0.8)$ & $2.3(1.2)$ & $2.2(0.9)$ & $1.8(0.4)$ & $1.4(0.2)$ & $2.0(1.0)$ \\
& High & $1.7(1.4)$ & $2.1(1.0)$ & $2.2(0.5)$ & $2.6(1.0)$ & $2.5(1.0)$ & $2.3(1.2)$ & $2.3(1.0)$ \\
& & & & & & & &
\end{tabular}

However, in spite of the drop in $\mathrm{pH}$, base cations also increased during succession. This can be explained by the increases in soil organic matter and cation exchange sites and concurrent enhanced capacity of the soil to retain cycled base cations (see e.g. Berendse 1998). Also, the abundance of living grass roots in the topsoil increase with succession, resulting in especially higher levels of phosphate and potassium (Nye 1968). Plant available ammonium, nitrate, potassium and phosphate increased during succession as well, nutrients promoting biomass production and accumulation of soil organic matter. Of both $\mathrm{N}$ forms, ammonium becomes the dominant $\mathrm{N}$ form in later succession stages, probably as a result of better adsorption of ammonium from atmospheric deposition to soil organic matter.

\section{Effects of $\mathrm{N}$ deposition on the vegetation}

High $\mathrm{N}$ deposition seemed to affect the composition of the vegetation. The total number of species was lower in high-deposition areas. For vascular plants, field surveys in the same sites by Nijssen et al. (2011) have shown that herbs like Jasione montana and Filago minima occurred more frequently in lowdeposition sites. However, those species are always present at very low densities, which made it impossible to detect differences in abundance with the method used in this paper.

Pinus sylvestris and Spergula morisonii showed a strong affinity with high-deposition sites. These species usually settle in early succession stages with low N availability (Sparrius 2011), and may thus profit from higher N. Although survival of young trees strongly depends on moisture conditions, a higher abundance of seedlings can be seen as an indicator for permanent settlement of trees, which is a problem in inland dunes, as removal of young trees is the most frequently applied conservation measure to maintain the open landscape (Riksen et al. 2008; Nijssen et al. 2011).

Higher algal cover was also found by van den Berg et al. (2005b), who found a three-fold increase of algal biomass after fertilization with a dose equivalent to $80 \mathrm{~kg} \mathrm{~N} \mathrm{ha}^{-1}$ year $^{-1}$ on calcareous dune sand at a site with $1 \mathrm{~kg} \mathrm{~N}^{-1}$ year $^{-1}$ background deposition.

The decrease in number of lichen species at high $\mathrm{N}$ deposition corresponds with the general decrease of lichens with application of $\mathrm{N}$ (Gordon et al. 2001; Soudzilovskaia et al. 2005; Hasse and Daniëls 2006; Britton and Fisher 2010; Sparrius 2011). The decrease in lichen species was most prominent in vegetation dominated by small cup-lichens. Effects for individual species were more difficult to detect, as they were mainly present in low densities. Two lichens Cetraria aculeata and Cladonia floerkeana of early succession stages with patches of bare soil and a perennial herb showed a clear preference for low-deposition sites. Common species of later succession stages, such as the lichens Cladonia gracilis, C. macilenta, $C$. ramulosa and the moss Dicranum scoparium even showed a preference for high-deposition areas, which suggests that they are less sensitive to $\mathrm{N}$ deposition than smaller species. Apart from C. zopfii, all these species have a much wider distribution than typical inland dune species and also occur on decomposing litter (Hasse 2005) and pine stumps (Daniëls 1983). C. macilenta and Dicranum scoparium also occur 
widely on wood and epiphytic (van Herk and Aptroot 2004; Siebel and During 2006). This suggests that in sites with high $\mathrm{N}$ deposition, typical inland dune lichens seem to be replaced by more ubiquitous species. The gramenoid Carex arenaria was mainly found in sites with high $\mathrm{N}$ deposition. In lime-poor coastal dunes, $C$. areneria is the main threat to species-rich pioneer vegetation as its leaf litter decomposes slowly (Kooijman and Besse 2002).

\section{Effects of $\mathrm{N}$ deposition on the soil}

Within the range of succession stages, soil carbon content is the most important factor explaining $\mathrm{pH}$ and $\mathrm{N}$ availability (Berendse 1998; Hasse 2005; KetnerOostra and Sýkora 2008; Sparrius 2011). However, $\mathrm{N}$ deposition seemed to play a role as well. Differences between low and high deposition sites were found with respect to indicators of soil acidification, such as $\mathrm{pH}$ and the ratio between $\mathrm{Al}$ and $\mathrm{Ca}$. This can be explained by atmospheric deposition of protons and proton producing substances, such as sulphur in the past (Bleeker and Erisman 1996; Eerens and van Dam 2001). As atmospheric N deposition mainly originates from lifestock breeding, high-deposition sites have elevated ammonium levels whereas deposition of nitrate is more or less equal in high and low-deposition sites. This difference in atmospheric deposition is reflected in a higher ammonium:nitrate ratio in the soil. Ammonium causes displacement of especially the less bound $\mathrm{Ca}^{2+}$ ions, compared to the stronger bound $\mathrm{Al}^{3+}$ on cation exchanges sites (van Breemen et al. 1983; Bowman et al. 2008). Ammonium may also stimulate nitrification by the increased amount of substrate for nitrifying bacteria (van Breemen et al. 1983; Sparrius 2011), which is also responsible for soil acidification The observed increase in the Al:Ca ratio could be due to increased release of $\mathrm{Al}$ from fines, which are sequioxides and clay coatings on soil particles. Al dissolution is considerably enhanced by the drop in pH (Sevink and de Waal 2010).

\section{Conclusions}

Drift sand succession seems to be mainly driven by an increase in organic matter, but is accelerated by nitrogen deposition. Solum depth, nutrient availability and amount of base cations of the soil increased during succession, along with the increase in soil organic matter, and despite the decrease in $\mathrm{pH}$. Increased $\mathrm{N}$ deposition cause cation displacement from cation exchange sites and leaching of base cations from the top soil resulting in a lower $\mathrm{pH}$ and higher $\mathrm{Al}: \mathrm{Ca}$ and $\mathrm{NH}_{4}: \mathrm{NO}_{3}$ ratios. The vegetation is affected by nitrogen deposition, promoting growth of algae, seedlings of Pinus sylvestris and some other species of late succession stages, but reducing diversity in lichens.

Acknowledgements The authors wish to thank L. Hoitinga, P.E. Wartenbergh, and A.J. van Wijk for help with analyzing samples, Dr H.F. van Dobben for advice on the nitrogen deposition data and Prof. L. Stroosnijder and two anonymous referees for commenting on the manuscript. This research was financially supported by OBN program of the Dutch Ministry of Economic Affairs, Agriculture and Innovation.

Open Access This article is distributed under the terms of the Creative Commons Attribution Noncommercial License which permits any noncommercial use, distribution, and reproduction in any medium, provided the original author(s) and source are credited.

\section{References}

Aptroot A, van Herk CM, Sparrius LB, Spier JL (2004) Checklist van de Nederlandse korstmossen en korstmosparasieten. Buxbaumiella 69:17-55

Berendse F (1998) Effects of dominant plant species on soils during succession in nutrient-poor ecosystems. Biogeochemistry $42: 73-88$

Biermann R, Daniëls FJA (1997) Changes in a lichen-rich dry sand grassland vegetation with special reference to lichen synusiae and Campylopus introflexus. Phytocoenologia 27:257-273

Bijlsma RJ (2010) Bryophyte hot-spots in drift sand forests. In: Fanta J, Siepel H (eds) Inland drift sand landscapes. KNNV, Zeist, pp 217-234

Bleeker A, Erisman J-W (1996) Depositie van verzurende componenten in Nederland in de periode 1980-1995. Report 722108018. RIVM, Bilthoven

Bowden RD (1991) Inputs, outputs and accumulation of nitrogen in an early successional moss (Polytrichum) ecosystem. Ecol Monogr 61:207-223

Bowman WD, Cleveland CC, Halada L, Hresko J, Baron JS (2008) Negative impact of nitrogen deposition on soil buffering capacity. Nat Geosci 1:767-770

Britton AJ, Fisher JM (2010) Terricolous alpine lichens are sensitive to both load and concentration of applied nitrogen and have potential as bioindicators of nitrogen deposition. Environ Pollut 158:1296-1302 
Bültmann H, Daniëls FJA (2001) Lichen richness-biomass relationship in terricolous lichen vegetation on noncalcareous substrates. Phytocoenologia 31:537-570

Daniëls FJA (1983) Lichen communities on stumps of Pinus sylvestris L. in the Netherlands. Phytocoenologia 11:431444

Daniëls FJA, Biermann R, Breder C (1993) Über KryptogamenSynusien in Vegetationskomplexen binnenländischer Heidelandschaften. Berichte der Reinhold-Tüxen-Gesellschaft 5:199-219

Daniëls FJA, Minarski A, Lepping O (2008) Long-term changes in the pattern of a Corynephorion grassland in the inland of the Netherlands. Annali di Botanica, ns 8:9-19

de Graaf MCC, Bobbink R, Verbeek PJM, Roelofs JGM (1997) Aluminium toxicity and tolerance in three heathland species. Water Air Soil Poll 98:229-239

de Haan BJ, Kros J, Bobbink R, van Jaarsveld JA, de Vries W, Noordijk H (2008) Ammoniak in Nederland. Bilthoven

Eerens HC, van Dam JD (eds) (2001) Grootschalige luchtverontreiniging en depositie in de Nationale Milieuverkenning 5. Rapport 408129016. Rijksinstituut voor Volksgezondheid en Milieuhygiene, Bilthoven

Gordon C, Wynn JM. Woodin SJ (2001) Impacts of increased nitrogen supply on high Arctic heath: the importance of bryophytes and phosphorus availability. New Phytol 149:461-471

Guo YR, Zhao HL, Zuo XA, Drake S, Zhao XY (2008) Biological soil crust development and its topsoil properties in the process of dune stabilization, Inner Mongolia. China Environ Geol 54:653-662

Hasse T (2005) Charakterisierung der Sukzessionsstadien im Spergulo-Corynephoretum (Silbergrasfluren) unter besonderer Berücksichtigung der Flechten. Tuexenia 25:407-424

Hasse T, Daniëls FJA (2006) Species responses to experimentally induced habitat changes in a Corynephorus grassland. J Veg Sci 14:135-146

Ketner-Oostra R, Sýkora KV (2008) Vegetation change in a lichen-rich inland drift sand area in the Netherlands. Phytocoenologia 38:267-286

Kooijman AM, Besse M (2002) The higher availability of $\mathrm{N}$ and $\mathrm{P}$ in lime-poor than in lime-rich coastal dunes in the Netherlands. J Ecol 90:394-403

Kooijman AM, Dopheide JCR, Sevink J, Takken I, Verstraten JM (1998) Nutrient limitations and their implications on the effects of atmospheric deposition in coastal dunes; lime-poor and lime-rich sites in the Netherlands. J Ecol 86:511-526

Kooijman AM, Lubbers I, van Til M (2009) Iron-rich dune grasslands: relations between soil organic matter and sorption of Fe and P. Environ Pollut 157:3158-3165

Masselink AK (1994) Pionier- en licheenrijke begroeiingen op stuifzanden benoorden de grote rivieren; typologie en syntaxonomie. Stratiotes 8:32-62

Moszynska B (1991) The regulation of matter transfer from plants to soil during primary forest succession on blown-out areas in the Dutch drift sands. p. 43. De Dorschkamp, Research Institute for For and Landscape Planning, Wageningen

Nijssen M, Riksen MPJM, Sparrius LB, Bijlsma RJ, van den Burg A, van Dobben HF, Jungerius PD, Ketner-Oostra HGM, Kooijman AM, Kuiters AL, van Swaay C, van Turnhout C, de Waal R (2011) Effectgerichte maatregelen voor het herstel en beheer van stuifzanden. OBN stuifzandonderzoek 2006-2010. Directie Kennis en Innovatie, Ministerie van Economische Zaken, Landbouw en Innovatie, Den Haag

Nye PH (1968) Processes in the root environment. J Soil Sci 19:205-215

Ott WR (1978) Environmental indices: theory and practice. Ann Arbor Science, Ann Arbor

Paus S (1997) Die Erdflechtenvegetation Nordwestdeutschlands und einiger Randgebiete. Bibliotheca Lichenologica 66:1-222

Prach K, Fanta J, Lukešová A, Liška J (1993) De ontwikkeling van de vegetatie op stuifzand van de Veluwe. Gorteria 19:73-79

Riksen M, Goossens D (2007) The role of wind and splash erosion in inland drift-sand areas in the Netherlands. Geomorphology 88:179-192

Riksen M, Spaan W, Stroosnijder L (2008) How to use wind erosion to restore and maintain the inland drift-sand ecotype in the Netherlands? J Nat Conserv 16:26-43

Sevink J, de Waal R (2010) Soil and humus development in drift sands. In: Fanta J, Siepel H (eds) Inland drift sand landscapes. KNNV, Zeist, pp 107-137

Siebel HN, During HJ (2006) Beknopte mosflora van Nederland en België. KNNV, Utrecht

Smit A, Kooijman AM, Sevink J (2002) Impact of grazing on litter decomposition and nutrient availability in a grassencroached Scots pine forest. For Ecol Manage 158:117-126

Soudzilovskaia NA, Onipchenko VG, Cornelissen JHC, Aerts $\mathrm{R}$ (2005) Biomass production, $\mathrm{N}: \mathrm{P}$ rati and nutrient limitation in a Caucasian alpine tundra plant community. J Veg Sci 16:399-406

Sparrius LB (2011) Inland dunes in The Netherlands: soil, vegetation, nitrogen deposition and invasive species. Dissertation. University of Amsterdam, Amsterdam

Sparrius LB, Kooijman AM (2011) Invasiveness of Campylopus introflexus in drift sands depends on nitrogen deposition and soil organic matter. Appl Veg Sci 14:221-229

Tietema A (1992) Nitrogen cycling and soil acidification in forest ecosystems in the Netherlands. Dissertation. University of Amsterdam, Amsterdam

van Breemen N, Mulder J, Driscoll CT (1983) Acidification and alkalization of soils. Plant Soil 75:283-308

van den Ancker JAM, Jungerius PD, Mur LR (1985) The role of algae in the stabilization of coastal dune blowouts. Earth Surf Process Landf 10:189-192

van den Berg LJL, Dorland E, Vergeer P, Hart MAC, Bobbink R, Roelofs JGM (2005a) Decline of acid-sensitive plant species in heathland can be attributed to ammonium toxicity in combination with low pH. New Phytol 166:551-564

van den Berg LJL, Tomassen HBM, Roelofs JGM, Bobbink R (2005b) Effects of nitrogen enrichment on coastal dune grassland: a mesocosm study. Environ Pollut 138:77-85

van der Meijden R (2005) Heukels' flora van Nederland, 23rd edn. Wolters-Noordhoff, Groningen

van der Putten WH, van Dijk C, Peters BAM (1993) Plantspecific soil-borne diseases contribute to succession in foredune vegetation. Nature 362:53-56

van Herk CM, Aptroot A (2004) Veldgids korstmossen. KNNV, Utrecht

Weeda EJ, Doing H, Schaminée JHJ (1996) KoelerioCorynephoretea. In: Schaminée JHJ, Stortelder AHF, Weeda EJ (eds) De vegetatie van Nederland 3. Opulus, Uppsala, pp 61-144 